\title{
Folic acid supplementation normalizes the endothelial progenitor cell transcriptome of patients with type I diabetes: a case-control pilot study
}

\author{
Olivia van Oostrom ${ }^{1}$, Dominique PV de Kleijnn ${ }^{2,3}$, Joost O Fledderus ${ }^{1}$, \\ Mario Pescatori ${ }^{4}$, Andrew Stubbs ${ }^{4}$, Attie Tuinenburg ${ }^{1}$, Sai Kiang Lim ${ }^{5}$ and \\ Marianne C Verhaar*1
}

\begin{abstract}
Address: ${ }^{1}$ Department of Nephrology and Hypertension, University Medical Center Utrecht, Utrecht, the Netherlands, ${ }^{2}$ Department of Experimental Cardiology, University Medical Center Utrecht, Utrecht, the Netherlands, ${ }^{3}$ Interuniversity Cardiology Institute of the Netherlands, Utrecht, The Netherlands, ${ }^{4}$ Department of Bioinformatics, Erasmus MC, Rotterdam, the Netherlands and ${ }^{5}$ Institute of Medical Biology, A*STAR, Singapore

Email: Olivia van Oostrom - o.vanoostrom@umcutrecht.nl; Dominique PV de Kleijn - dkleijn@umcutrecht.nl;

Joost O Fledderus - j.o.fledderus@umcutrecht.nl; Mario Pescatori - m.pescatori@erasmusmc.nl; Andrew Stubbs - a.stubbs@erasmusmc.nl; Attie Tuinenburg - a.tuinenburg-2@umcutrecht.nl; Sai Kiang Lim - saikiang.lim@imb.a-star.edu.sg;

Marianne C Verhaar* - m.c.verhaar@umcutrecht.nl

* Corresponding author
\end{abstract}

Published: 25 August 2009

Cardiovascular Diabetology 2009, 8:47 doi:10.1 186/1475-2840-8-47

This article is available from: http://www.cardiab.com/content/8///47

(C) 2009 van Oostrom et al; licensee BioMed Central Ltd.

This is an Open Access article distributed under the terms of the Creative Commons Attribution License (http://creativecommons.org/licenses/by/2.0), which permits unrestricted use, distribution, and reproduction in any medium, provided the original work is properly cited.

\begin{abstract}
Background: Endothelial progenitor cells play an important role in vascular wall repair. Patients with type I diabetes have reduced levels of endothelial progenitor cells of which their functional capacity is impaired. Reduced nitric oxide bioavailability and increased oxidative stress play a role in endothelial progenitor cell dysfunction in these patients. Folic acid, a B-vitamin with anti-oxidant properties, may be able to improve endothelial progenitor cell function. In this study, we investigated the gene expression profiles of endothelial progenitor cells from patients with type I diabetes compared to endothelial progenitor cells from healthy subjects. Furthermore, we studied the effect of folic acid on gene expression profiles of endothelial progenitor cells from patients with type I diabetes.
\end{abstract}

Methods: We used microarray analysis to investigate the gene expression profiles of endothelial progenitor cells from type I diabetes patients before $(n=I I)$ and after a four week period of folic acid supplementation $(n=10)$ compared to the gene expression profiles of endothelial progenitor cells from healthy subjects $(n=1 \mathrm{I})$. The probability of genes being differentially expressed among the classes was computed using a random-variance $t$-test. A multivariate permutation test was used to identify genes that were differentially expressed among the two classes. Functional classification of differentially expressed genes was performed using the biological process ontology in the Gene Ontology database.

Results: Type I diabetes significantly modulated the expression of I59I genes compared to healthy controls. These genes were found to be involved in processes regulating development, cell communication, cell adhesion and localization. After folic acid treatment, endothelial progenitor cell gene expression profiles from diabetic patients were similar to those from healthy controls. Genes that were normalized by folic acid played a prominent role in development, such as the transcription factors IDI and MAFF. Few oxidative-stress related genes were affected by folic acid.

Conclusion: Folic acid normalizes endothelial progenitor cell gene expression profiles of patients with type I diabetes. Signaling pathways modulated by folic acid may be potential therapeutic targets to improve endothelial progenitor cell function. 


\section{Background}

Diabetes mellitus (DM) is a major risk factor for microand macrovascular complications $[1,2]$ and is associated with endothelial dysfunction, premature atherosclerosis [3-5], and a reduced capability of neovascularization in ischemic conditions[6]. Hyperglycemia increases the production of superoxide $\left(\mathrm{O}_{2}^{-}\right)$and reduces the bioavailability of nitric oxide (NO) resulting in the development of endothelial dysfunction in diabetic patients[7,8]. Exposure to oxidative stress induces a pro-inflammatory response and increases endothelial cell apoptosis, which leads to a disturbance in the endothelial monolayer. The denuded vessel wall is highly pro-atherogenic, so fast regeneration of the endothelium is essential to prevent formation of atherosclerotic plaques $[9,10]$.

Besides repair of the endothelial monolayer by adjacent mature endothelial cells, circulating bone marrowderived endothelial progenitor cells (EPC) are also recognized to play an important role in reendothelialization [11-15]. Furthermore, studies have shown that ex vivo expanded EPC can home to sites of ischemia, express endothelial markers and improve neovascularization and tissue regeneration [16-18]. In addition, clinical trials are ongoing to evaluate the regenerative capacity of EPC in patients with ischemic limb or heart disease[19]. Patients with cardiovascular risk factors, such as type 1 or $2 \mathrm{DM}$, have decreased numbers of EPC and these show impaired functional capacity [20-24]. Mechanisms underlying endothelial dysfunction, such as reduced NO bioavailability and increased oxidative stress also play a role in EPC dysfunction in patients with DM[25,26].

Increasing NO bioavailability by improving endothelial nitric oxide synthase (eNOS) function can be achieved by folic acid (FA) supplementation. The active form of FA, 5methyltetrahydrofolate restores the function of uncoupled eNOS by increasing the availability of its cofactor tetrahydrobiopterin $\left(\mathrm{BH}_{4}\right)$ [27]. Studies have shown that FA supplementation restores endothelial function in patients with coronary artery disease[28,29], hyperhomocysteinemia [30-32], hypercholesterolemia [33-35], and type 1 and 2 DM [36-38]. Recently, it was shown that cardiac function can be preserved after ischemia in FA-treated rats[39]. In addition, exogenous $\mathrm{BH}_{4}$ improves pre-existing advanced cardiac hypertrophy and fibrosis in mice[40]. These studies[39,40] describe novel beneficial effects of FA, suggesting that its therapeutic potential in cardiovascular disease still remains to be fully elucidated. At the molecular level, the effects of DM on EPC are not well characterized. Although a role for oxidative stress in modulating EPC number and function has been implied[25,26], the effects of DM on EPC gene expression remain unclear. Autologous progenitor cell-based therapy may not reach its true potential in diabetic patients when their own progenitor cells are impaired. Therefore, a likely therapeutic strategy may be the modulation of EPC levels and/or function. Increased understanding of the mechanisms leading to the numerical and functional impairment of EPC is necessary. In this study, we investigated the gene expression profiles of EPC in DM type 1 (DM1) patients compared to healthy subjects. Furthermore, we show that FA can change the gene expression profiles of EPC from DM1 patients to resemble those of healthy subjects.

\section{Methods \\ Subjects}

Patients with DM1 $(n=20)$, diagnosed at least 1 year before entering the study, were recruited from the outpatient clinic of the Department of Internal Medicine of the University Medical Centre Utrecht, The Netherlands. Exclusion criteria were presence of manifest macrovascular disease, liver disease, homocysteine $>15 \mu \mathrm{mol} / \mathrm{l}$, creatinine $>120 \mu \mathrm{mol} / \mathrm{l}$ and untreated thyroid disease. If patients were being treated with vasoactive medication (angiotensin converting enzyme inhibitors, angiotensin II antagonists, statins, nonsteroidal anti-inflammatory drugs (NSAIDs), FA or vitamins), treatment was stopped at least 3 weeks before initiation of the study. Twenty ageand gender-matched healthy subjects served as controls. Cardiovascular risk was evaluated by a questionnaire and clinical parameters such as weight, length and blood pressure were measured.

Peripheral blood samples were collected from 20 patients with DM1 and 20 age- and gender-matched healthy control subjects (CTR) at baseline. Patients with DM1 were then treated for 4 weeks with FA (Ratiopharm) $5 \mathrm{mg} /$ day after which peripheral blood samples were collected again (19 of the 20 patients). The study protocol was approved by the Medical Ethical Committee of the University Medical Centre Utrecht. All participants in the study gave their written informed consent.

\section{EPC Culture}

Peripheral blood samples $(90 \mathrm{ml})$ were collected in EDTA tubes (Greiner Bio-One) and mononuclear cells (MNC) were isolated using Ficoll density gradient centrifugation (Ficoll-Paque Plus; GE Healthcare Bio-Sciences). MNC were plated on human fibronectin (Becton Dickinson)coated six-well plates (Corning) at a density of $5 \times 10^{6}$ cells/ml of EGM-2 medium (Cambrex), supplemented with $20 \%$ fetal calf serum (Invitrogen), $100 \mathrm{ng} / \mathrm{ml}$ recombinant VEGF-165 (R\&D systems) and antibiotics (penicillin $100 \mathrm{U} / \mathrm{ml}$ and streptomycin $100 \mu \mathrm{g} / \mathrm{ml}$; Invitrogen). Mononuclear cells were kept in a stove at $37^{\circ} \mathrm{C}$, for 7 days, allowing differentiation to EPC. At day 4, medium was changed to wash away non-adherent cells. Cells used for quantification were detached by using trypsin-EDTA (Inv- 
itrogen) and gentle cell scraping, followed by counting on a hemocytometer (Cell-Dyn 1800, Abbott Diagnostics). EPC were cultured as previously described[41]. EPC phenotype of attaching cells was confirmed by the presence of endothelial surface markers, the binding of Ulex Europaeus Agglutinin-1 and the uptake of DiI-labeled acetylated LDL.

\section{Microarray Analysis}

Total RNA was extracted from Trizol $^{\circledast}$ (Invitrogen)-treated EPC samples from $20 \mathrm{DM} 1$ patients before and after treatment with FA, and 20 age- and gender-matched healthy control subjects according to manufacturer's instructions. One sample from a FA treated DM1 patient was excluded due to low total RNA yield. Chromosomal DNA was removed from the samples by treatment with DNase I (Amersham Biosciences). The concentration of the isolated RNA was determined with the Nanodrop ND-1000 spectrophotometer (Nanodrop Technologies). The samples were independent isolates from single donors.

Microarray analysis was performed on EPC samples from a subset of the patient population i.e. $11 \mathrm{DM} 1$ patients, 10 DM1 patients after FA and 11 healthy controls. Doublestranded cDNA was synthesized from $125 \mathrm{ng}$ of total RNA and in vitro transcription was performed to generate biotinylated cRNA using the Illumina ${ }^{\circledR}$ TotalPrep ${ }^{\mathrm{TM}}$ RNA Amplification Kit (Ambion) according to the manufacturer's instructions. From each sample, 850 ng of cRNA was hybridized overnight at $55^{\circ} \mathrm{C}$ to Sentrix HumanRef-8 Expression BeadChips (Illumina), containing 23000 genes. The following day the BeadChips were washed and a signal was developed with streptavidin-Cy3 (Amersham Biosciences). Chips were scanned with a BeadArray Reader (Illumina).

Raw gene array bead summary intensities were extracted using Beadstudio version 3.2 (Illumina) and quantile normalized in R/Bioconductor. Normalized bead summary intensities were imported in BRB-ArrayTools (developed by Dr. Richard Simon and BRB-ArrayTools Development Team) for further analysis. Microarray data are available at http://www.ncbi.nlm.nih.gov/geo/, accession number GSE17635.

\section{Statistical Analysis}

Differences in EPC numbers between patients with DM1 and healthy controls, and patients with DM1 before and after FA treatment were determined by a Mann Whitney or Wilcoxon signed rank test respectively. A p value $<0.05$ was considered statistically significant.

The probability of genes being differentially expressed among the classes was computed using a random-variance $\mathrm{t}$-test. The random-variance $\mathrm{t}$-test is an improvement over the standard separate t-test as it permits sharing information among genes about within-class variation without assuming that all genes have the same variance[42], A multivariate permutation test was used to identify genes that were differentially expressed among the two classes $[43,44]$. The multivariate permutation test provides $90 \%$ confidence that the false discovery rate (FDR) is less than $10 \%$. The test statistics used are random variance $\mathrm{t}-$ statistics for each gene[42]. Although t-statistics were used, the multivariate permutation test is non-parametric and does not require the assumption of Gaussian distributions. Gene clusters with similar gene expression patterns across sample classes were identified by using hierarchical clustering (Pearson 1 - correlation distances) on normalized bead signal intensities. Functional classification of differentially expressed genes was performed using the biological process ontology in the Gene Ontology database (GO; http://www.geneontology.org). Classification was listed if a biological process term was significantly overrepresented or underrepresented among differentially expressed genes as compared to the Homo sapiens reference genome.

\section{Results}

\section{Patient Characteristics}

Patient characteristics are summarized in Table 1. The group of diabetic patients is representative of a type 1 diabetic population without macrovascular complications. Retinopathy was present in 4 patients. None of the

Table I: Characteristics of patients with DMI. Data are mean \pm SEM.

\begin{tabular}{lc}
\hline & Type I diabetic patients $(\mathrm{n}=20)$ \\
\hline Age (years) & $34.2 \pm 6.4$ \\
Gender (male/female) & $8 / / 2$ \\
Body mass index $\left(\mathrm{kg} / \mathrm{m}^{2}\right)$ & $22.8 \pm 1.7$ \\
Blood pressure $(\mathrm{mmHg})$ & $128 \pm 13$ \\
$\quad$ Systolic & $83 \pm 8$ \\
$\quad$ Diastolic & $14.0 \pm 6.6$ \\
Duration of diabetes (years) & \\
Medication & $20 / 20$ \\
Insulin & $2 / 20$ \\
Antihypertensive drugs & $1 / 20$ \\
NSAIDs & $1 / 20$ \\
Statin & $8 / 12$ \\
Oral anti conception & $3 / 20$ \\
Folic acid & $6 / 20$ \\
Current smoker & $8.4 \pm 3.6$ \\
Glucose (mmol/l) & $8.2 \pm 0.6$ \\
HbAlc $(\%)$ & $8.2 \pm 2.5$ \\
Homocysteine $(\mu \mathrm{mol} / \mathrm{l})$ & $4.3 \pm 0.6$ \\
Total cholesterol $(\mathrm{mmol} / \mathrm{l})$ & $2.3 \pm 0.5$ \\
LDL (mmol/l) & $1.6 \pm 0.2$ \\
HDL (mmol/l) & $0.9 \pm 0.3$ \\
Triglycerides $(\mathrm{mmol} / \mathrm{l})$ & \\
&
\end{tabular}


patients had microalbuminuria. Antihypertensive drugs, statins and FA supplementation were stopped at least 3 weeks before initiation of the study. Age and gendermatched healthy controls did not significantly differ in body mass index and blood pressure from patients with DM1. FA treatment did not have any effect on the characteristics.

\section{Effect of DMI on EPC Number}

We assessed the number of EPC obtained after 7-day culturing of peripheral blood MNC from patients with DM1 before $(n=20)$ and after 4 weeks $(n=19)$ of treatment with FA and from healthy control subjects $(n=20)$. We observed a $26 \%$ decrease in the mean number of EPC from DM1 patients compared to healthy control subjects $\left(25575 \pm 4891\right.$ versus $34375 \pm 5065 \mathrm{EPC} / 10^{6} \mathrm{MNC} ; \mathrm{p}=$ 0.057). After FA treatment, the mean number of EPC tended to increase slightly by $17 \%(25575 \pm 4891$ versus $29868 \pm 3754 \mathrm{EPC} / 10^{6} \mathrm{MNC} ; \mathrm{p}=0.14$ ) (Figure 1). No significant differences in EPC number were observed between healthy controls and DM1 patients after FA $\left(34375 \pm 5065\right.$ versus $29868 \pm 3754 \mathrm{EPC} / 10^{6} \mathrm{MNC} ; \mathrm{p}=$ $0.37)$.

\section{Differential Gene Expression in EPC from Patients With} DMI Before and After FA Treatment and Healthy Controls Whole genome microarray analysis was performed to compare gene expression profiles of EPC from patients with DM1 before and after FA treatment and healthy controls. At a FDR of 0.05 , a total of 2170 genes were differentially expressed between DM1 patients before and after FA treatment and healthy controls. This set of genes was used for hierarchical clustering analysis. The dendrogram in Figure 2 demonstrates the close correlation of the gene

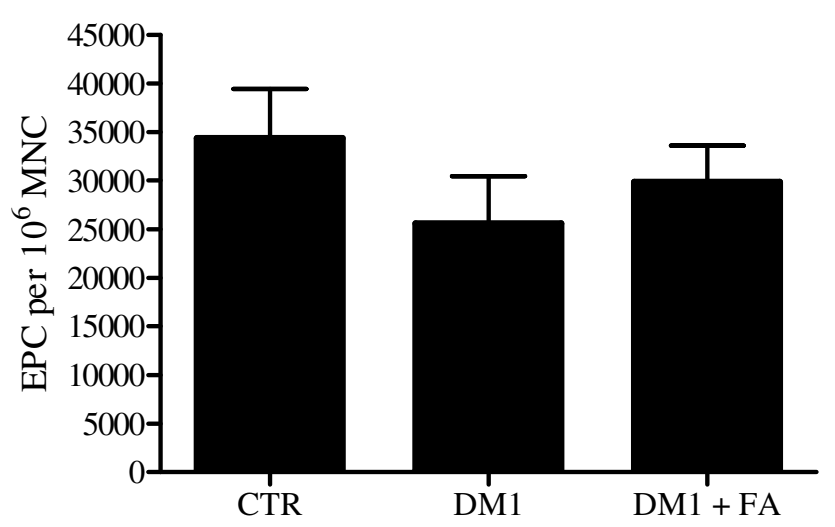

Figure I

Effect of DMI on EPC number. EPC number from diabetic patients before (DMI, $n=20)$ and after treatment with FA (DMI + FA, $n=19)$ and from age- and gender-matched healthy control subjects $(C T R, n=20)$. Data are presented as mean \pm SEM.

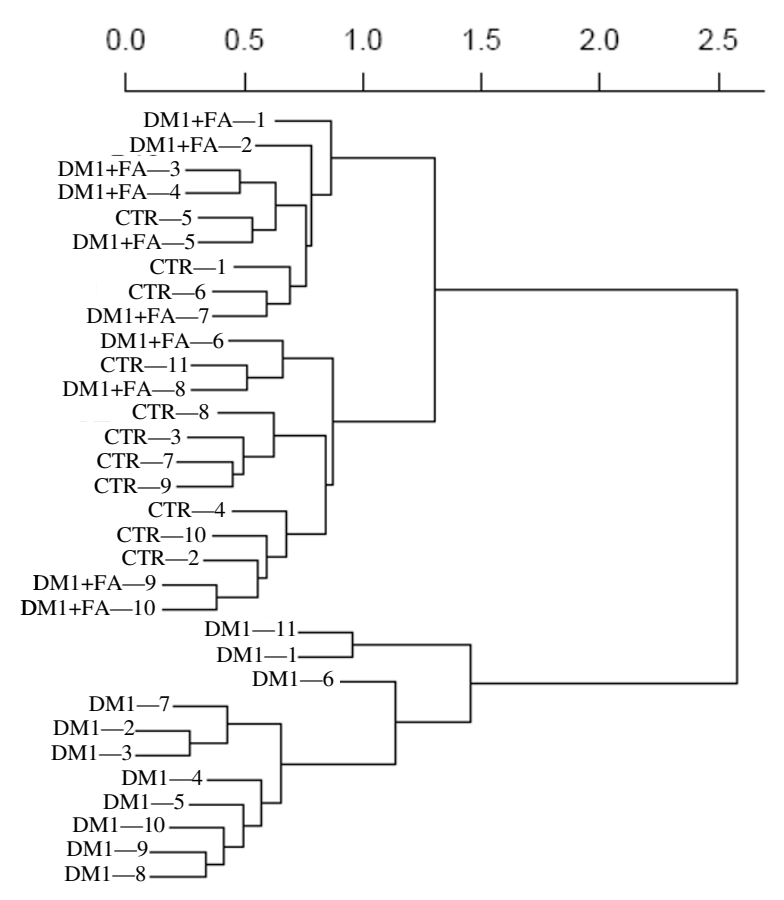

Figure 2

Similarity of gene expression profiles of EPC between healthy controls and FA-treated DMI patients. Unsupervised hierarchical clustering based on gene expression of EPC from DMI patients before and after FA treatment and healthy controls. Clustering of conditions partitioned samples into 2 groups. The gene expression profiles of healthy controls (CTR) and FA-treated DMI patients are clustered together as a distinct group, separated from the gene expression profiles of EPC from patients with DMI before FA-treatment.

expression profiles of EPC from FA-treated DM1 patients and healthy controls which are clustered together while gene expression profiles of EPC from DM1 patients are placed in a distinct group.

The result of the differential gene expression analysis is summarized in Figure 3 with the Venn diagram depicting the distribution of 2170 probe sets found to be differentially expressed in EPC in at least 1 comparison at a FDR of 0.05. 1591 genes are differentially expressed between DM1 patients and healthy controls, and 1092 genes are differentially expressed in DM1 patients before and after FA. The intersect shows that 513 genes with differential expression between healthy controls and DM1 are also modulated by FA treatment. Gene expression profiles of EPC from healthy controls and DM1 patients after FA were very similar and pairwise comparison shows no differentially expressed genes at a 0.05 FDR level. 
DM1 versus CTR

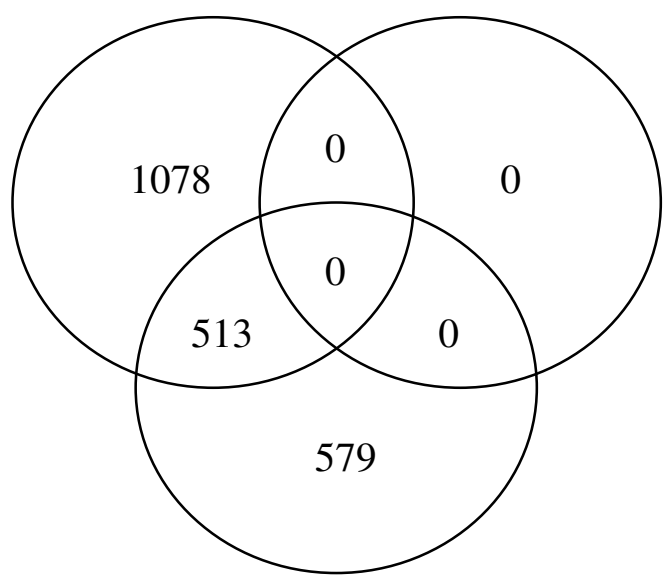

DM1 versus DM1 + FA
Figure 3

A Venn diagram depicting differential gene expression. The distribution is represented of 2170 probe sets found to be differentially expressed in EPC in at least I comparison (DMI, DMI + FA, CTR) at a FDR of 0.05 .

\section{Classification of Differentially Expressed Genes in EPC of Patients With DMI Compared to Healthy Controls}

To investigate the effect of DM1 on EPC gene expression on a more functional level, differentially regulated genes in EPC of patients with DM1 compared to healthy controls were classified into Gene Ontology (GO) terms (Table 2). Fifty-five GO terms with a p value of less than 0.01 in the differentially expressed gene set were enriched compared to a random gene set of equal size, resulting in an enrichment including 'cell communication', 'developmental process', 'localization', 'cell proliferation' and 'cell adhesion'. 30\% of the differentially regulated genes were involved in cell communication, including members of the desintegrin and metalloproteinase domain family (upregulated HOXD9, ID1, NFATC3; downregulated MAFF, HOXB8, HOXD8), interleukin family (upregulated IL12RB1，IL12RB2，IL13，IL18，IL1RAP; downregulated IL1RL1, IL9R), RAS GTPase superfamily (upregulated RAB39B, RABL2A, RASAL1, RASAL2, and RASD2; downregulated RAB11B, RAB27A, RAB3B, RABL4, RASA1) and TNF receptor family (downregulated TNFRSF-14, -17). $26 \%$ of the genes were categorized into the GO term 'developmental process', including members of the fibroblast growth factors (upregulated FGF3, FGF11), transcription regulators (upregulated HOXD9, ID1, NFATC3; downregulated MAFF, HOXB8, HOXD8), and members of the wingless-type (Wnt) pathway (upregulated FRZB, WNT10B, WNT11).
Cell adhesion plays an important role in progenitor cell biology and has previously been shown to be impaired in EPC from DM patients[24]. We therefore examined genes that were affected in our DM1 population and could potentially have a role in EPC adhesion. We found that members of the protocadherin family involved in calcium-dependent cell adhesion (upregulated PCDH8, PCDHB8, PCDHB9, PCDHGA4, PCDHGB3; downregulated PCDHA8, PCDHGA10, PCDHGA3, PCDHGA7, PCDHGB2), structural proteins (upregulated SPON1, COL13A1; downregulated COL21A1) and integrinrelated binding proteins (upregulated ADAM22, IBSP, ITGB1; downregulated ADAM2) were included in the category 'cell adhesion'.

We also examined the genes categorized into GO terms 'response to stress' and 'response to hypoxia' because of the known effect of diabetes on oxidative stress-related signaling. These genes included dual oxidase 2 (DUOX2), which is a NADPH oxidase and has the capacity to generate superoxide, nitric oxide synthase $2 \mathrm{~A}$ (NOS2A), which can produce nitric oxide, thioredoxin reductase 2 (TXNRD2), a key enzyme in the regulation of the intracellular redox balance, lactoperoxidase (LPO) and NADPH oxidase organizer 1 (NOXO1), which is involved in reactive oxygen species production, all of which were upregulated in EPC from patients with DM1.

\section{FA Normalizes Changes in Gene Expression in EPC From Patients With DMI}

Interestingly, 513 genes that were differentially expressed between healthy controls and patients with DM1 were normalized by FA treatment. Genes with this expression pattern are visualized in the heat map depicted in Figure 4. 390 genes were upregulated (cluster 1) and 123 genes (cluster 2) were downregulated in DM1 (for the complete list of gene names, see Additional file 1) and the expression of these genes was normalized to healthy control levels after FA treatment.

To more closely examine the observed effects of FA on diabetic EPC gene expression, we classified the 513 genes into Gene Ontology terms (Figure 5). Fourteen terms in the list had a p value of less than 0.01 . Strikingly, many of these processes are related to development, indicating a major effect of FA on developmental processes. Gene expression of fibroblast growth factor 3 (FGF3), transcriptional regulators (HOXD8, HOXD9, ID1, MAFF), and members of the Wnt pathway (FRZB, WNT11) was significantly different between DM1 and healthy controls and normalized by FA. We also examined the category 'cell adhesion', which was modulated by DM1 and found that FA regulated several members of the protocadherin family (PCDH8, PCDHB8, PCDHB9, PCDHGA10, PCDHGA4, PCDHGB3), structural protein collagen type XIII alpha 1 
Table 2: Classification of differentially expressed genes between healthy controls and DMI patients according to gene ontology (GO) terms with a $p$ value $<0.01$.

\begin{tabular}{|c|c|c|c|}
\hline Term & Category & $\%$ of genes in category & p value \\
\hline GO:003250I & multicellular organismal process & 32,02 & $9,28 \mathrm{E}-09$ \\
\hline GO:0007275 & multicellular organismal development & 21,45 & I,93E-07 \\
\hline GO:0048856 & anatomical structure development & 19,24 & $3,1 \mathrm{IE}-06$ \\
\hline GO:0007267 & cell-cell signaling & 7,89 & $5,22 \mathrm{E}-06$ \\
\hline GO:0006812 & cation transport & 6,94 & $5,94 \mathrm{E}-06$ \\
\hline GO:004873I & system development & 16,25 & $6,22 \mathrm{E}-06$ \\
\hline GO:0032502 & developmental process & 26,18 & I,94E-05 \\
\hline GO:00068II & ion transport & 8,99 & 2,27E-05 \\
\hline GO:003000I & metal ion transport & 5,52 & 7,57E-05 \\
\hline GO:0009605 & response to external stimulus & 7,10 & $\mathrm{I}, \mathrm{IIE}-04$ \\
\hline GO:00I5672 & monovalent inorganic cation transport & 4,57 & $\mathrm{I}, 19 \mathrm{E}-04$ \\
\hline GO:00485I3 & organ development & 11,83 & I,56E-04 \\
\hline GO:0006813 & potassium ion transport & 2,84 & 2,0IE-04 \\
\hline GO:005II79 & localization & 24,29 & $4,04 \mathrm{E}-04$ \\
\hline GO:000609I & generation of precursor metabolites and energy & 6,78 & $4,90 \mathrm{E}-04$ \\
\hline GO:0007I67 & enzyme linked receptor protein signaling pathway & 3,79 & $5,36 \mathrm{E}-04$ \\
\hline GO:00030I2 & muscle system process & 2,68 & $6,04 \mathrm{E}-04$ \\
\hline GO:0006936 & muscle contraction & 2,68 & $6,04 \mathrm{E}-04$ \\
\hline GO:0019226 & transmission of nerve impulse & 4,26 & 7,76E-04 \\
\hline GO:0007/88 & G-protein signaling, coupled to cAMP nucleotide second messenger & 1,74 & I,35E-03 \\
\hline GO:0008283 & cell proliferation & 7,57 & I,65E-03 \\
\hline GO:0006950 & response to stress & 9,62 & I,76E-03 \\
\hline GO:0008284 & positive regulation of cell proliferation & 3,15 & I,97E-03 \\
\hline GO:00096 II & response to wounding & 4,73 & I,99E-03 \\
\hline GO:0007I89 & G-protein signaling, adenylate cyclase activating pathway & 1,10 & 2,IIE-03 \\
\hline GO:0019933 & cAMP-mediated signaling & $\mathrm{I}, 74$ & 2,27E-03 \\
\hline GO:0006954 & inflammatory response & 3,63 & $2,53 \mathrm{E}-03$ \\
\hline GO:0007I54 & cell communication & 29,50 & $2,75 \mathrm{E}-03$ \\
\hline GO:0007I55 & cell adhesion & 7,26 & $2,76 \mathrm{E}-03$ \\
\hline GO:0022610 & biological adhesion & 7,26 & $2,76 \mathrm{E}-03$ \\
\hline GO:0006928 & cell motility & 4,57 & 2,8IE-03 \\
\hline GO:005I674 & localization of cell & 4,57 & 2,8IE-03 \\
\hline GO:003004I & actin filament polymerization & 0,95 & $3,08 \mathrm{E}-03$ \\
\hline GO:0044262 & cellular carbohydrate metabolic process & 3,94 & $3,72 \mathrm{E}-03$ \\
\hline GO:0007I56 & homophilic cell adhesion & 2,21 & $3,85 \mathrm{E}-03$ \\
\hline GO:0006952 & defense response & 5,68 & 4,07E-03 \\
\hline GO:003I 279 & regulation of cyclase activity & 1,10 & $4,16 \mathrm{E}-03$ \\
\hline GO:005I339 & regulation of lyase activity & 1,10 & $4,16 \mathrm{E}-03$ \\
\hline GO:0007I87 & G-protein signaling, coupled to cyclic nucleotide second messenger & 1,89 & $4,78 \mathrm{E}-03$ \\
\hline GO:001605I & carbohydrate biosynthetic process & 1,89 & $4,78 \mathrm{E}-03$ \\
\hline GO:0019317 & fucose catabolic process & 0,63 & $5,29 \mathrm{E}-03$ \\
\hline GO:0042355 & L-fucose catabolic process & 0,63 & $5,29 \mathrm{E}-03$ \\
\hline GO:0007I73 & epidermal growth factor receptor signaling pathway & 0,95 & $5,72 \mathrm{E}-03$ \\
\hline GO:0007268 & synaptic transmission & 3,47 & $5,92 \mathrm{E}-03$ \\
\hline GO:000I50I & skeletal development & 2,84 & $6,00 \mathrm{E}-03$ \\
\hline GO:0008I54 & actin polymerization and/or depolymerization & 1,26 & $6,04 \mathrm{E}-03$ \\
\hline GO:0007610 & behavior & 3,63 & $6,90 \mathrm{E}-03$ \\
\hline GO:0007I69 & transmembrane receptor protein tyrosine kinase signaling pathway & 2,52 & $6,99 \mathrm{E}-03$ \\
\hline GO:0019935 & cyclic-nucleotide-mediated signaling & 1,89 & $7,8 \mid E-03$ \\
\hline GO:0003008 & system process & 11,67 & $8,19 \mathrm{E}-03$ \\
\hline GO:0007626 & locomotory behavior & 2,52 & 8,37E-03 \\
\hline GO:0042I 27 & regulation of cell proliferation & 4,89 & $8,47 \mathrm{E}-03$ \\
\hline GO:0001666 & response to hypoxia & 1,10 & $9,08 \mathrm{E}-03$ \\
\hline GO:0042354 & L-fucose metabolic process & 0,63 & $9,17 \mathrm{E}-03$ \\
\hline GO:0043085 & positive regulation of catalytic activity & 2,84 & $9,54 \mathrm{E}-03$ \\
\hline
\end{tabular}




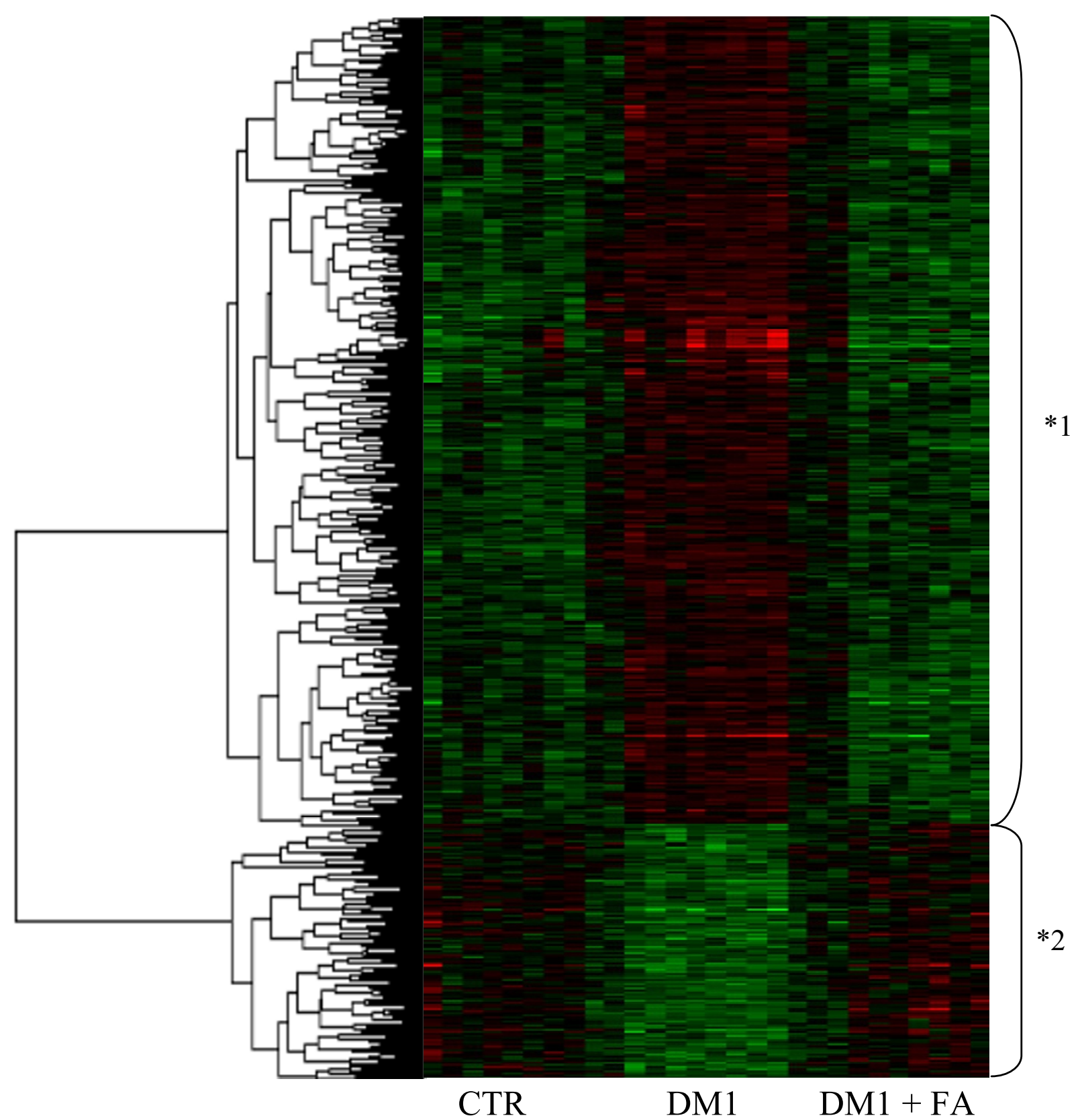

Log-intensities

\section{Figure 4}

Heat map display of genes that are normalized by FA in EPC of DMI patients. Visualization of mean-centered and normalized gene expression patterns of the $5 \mathrm{I} 3$ intersect genes with differential expression between healthy controls (CTR) and DMI patients that are normalized by FA treatment. The relative levels of gene expression are depicted with a color scale, where green represents the lowest and red the highest level of expression. Two main clusters of genes can be clearly identified as marked by an asterisk. 


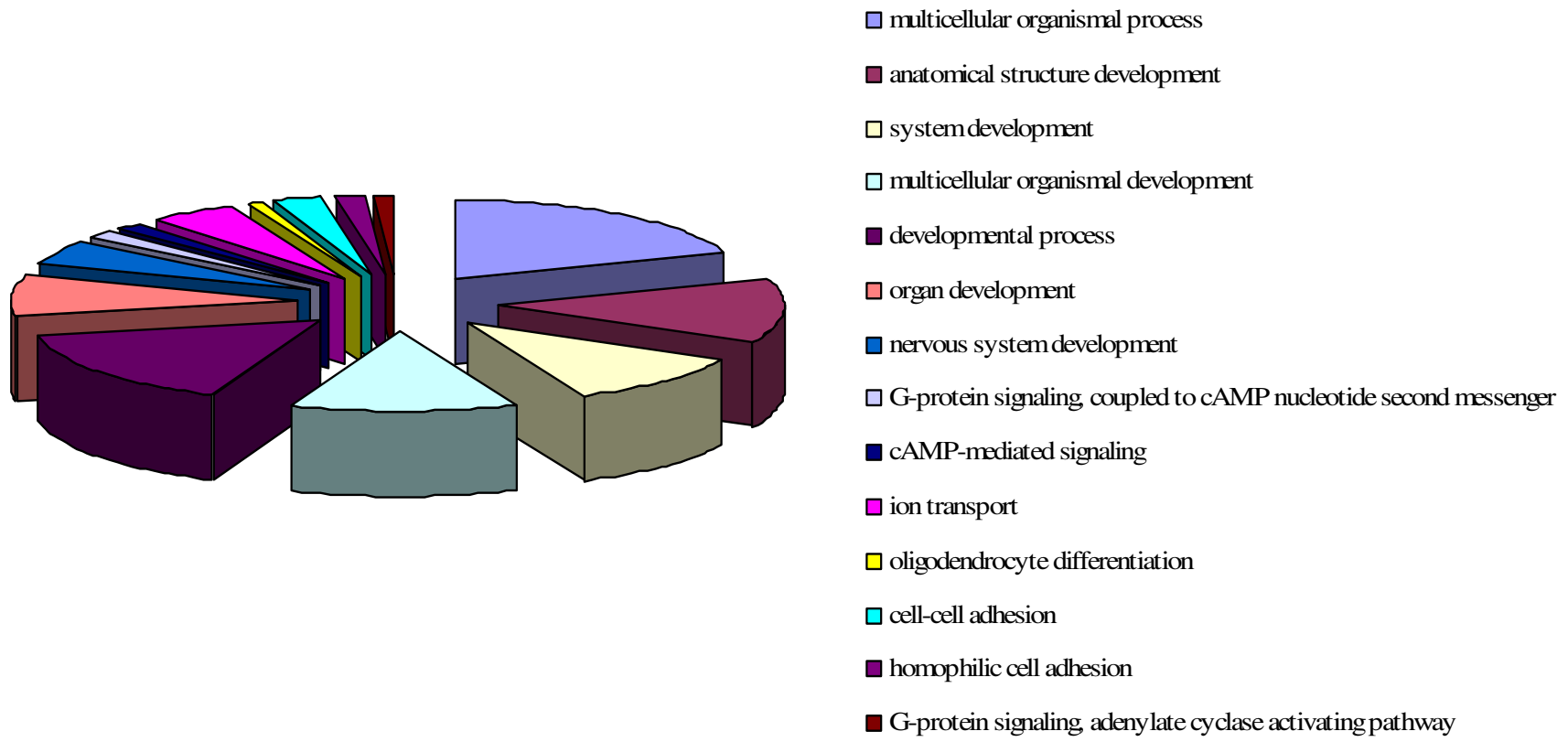

Figure 5

A pie chart representing classification of 5 I 3 genes into Gene Ontology terms. Biological processes, defined by genes that are normalized by FA treatment in EPC from patients with DMI, with a $p$ value $<0.01$ are listed.

(COL13A1) and integrin beta 1 (ITGB1). Furthermore, genes involved in $\mathrm{G}$ protein signaling including guanine nucleotide binding proteins (GNAL, GNAQ), cortistatin (CORT), gamma-aminobutyric acid $\mathrm{B}$ receptor 1 (GABBR1), gastric inhibitory polypeptide receptor (GIPR) and parathyroid hormone-like hormone (PTHLH) were regulated by FA. Four oxidative stress-related genes (DUOX2, NOS2A, NOXO1 and LPO) which were differentially expressed between DM1 and healthy controls returned to control levels by FA.

\section{Discussion}

In this study we investigated the effects of FA on the transcriptome of EPC from patients with DM1. We found that DM1, compared to healthy controls, modulates the expression of 1591 genes which are mainly involved in cell communication, development, localization, cell proliferation and cell adhesion. FA treatment for 4 weeks in patients with DM1 leads to the normalization of the gene expression of 513 of the 1591 genes. In particular, FA regulated genes that are involved in development, cell adhesion and $\mathrm{G}$ protein signaling.

This study describes differential gene expression profiling of EPC between patients with DM1 and healthy controls. Importantly, in order to be able to improve impaired numerical and functional capacity of EPC, identification of genes that are affected by DM1 is required. We observed an effect of DM1 on members of the desintegrin and met- alloproteinase domain family (ADAM17, ADAM22, ADAMTS14 and ADAMTS18) involved in cell communication. ADAM22, a membrane spanning protein, is one of the most strongly upregulated genes in DM1 compared to healthy controls. Little is known about this member of the ADAM family, however, it has been shown that other members such as ADAM17 can potentially play a role in angiogenesis and cytokine biology in inflammatory processes[45,46]. Of note, ADAM17, also known as TNF- $\alpha$ converting enzyme which is important in processing and release of TNF- $\alpha$ from the cell membrane, was significantly upregulated in EPC of DM1 patients[45,46].

Genes that also play a role in cell communication and development are members of the TNF receptor family (TNFRSF-14, and -17). TNFRSF-14 was significantly downregulated in EPC of DM1 patients compared to healthy controls. It has been described that this receptor can play a dual role in regulating $\mathrm{T}$ cell immune responses depending on ligand receptor interaction. Knockout animals are more susceptible to developing autoimmune diseases[47], and $\mathrm{T}$ cell survival depends on receptor activation[48]. In contrast, the receptor has been implicated to play a role in inflammatory diseases such as rheumatoid arthritis[49,50] and atherosclerosis[51]. So far, no studies have reported TNFRSF-14 expression in EPC, therefore it remains to be investigated what its potential role could be in EPC function. 
Other groups have performed microarray analysis on circulating cells from patients with DM1, in particular monocytes[52] and peripheral blood mononuclear cells[53]. As EPC are cultured from the peripheral blood mononuclear cell fraction and have been previously described as a monocyte-like cell[54], some overlap in gene expression between the different cell types can be expected. Interestingly, similar expression patterns were seen in EPC from DM1 patients in our study, and monocytes and peripheral blood mononuclear cells from DM1 patients in the other studies[52,53], for splicing factor, arginine/serine rich 15 (SFRS15), cell division cycle 42 (CDC42), interleukin 6 (IL6), heat shock $70 \mathrm{kDa}$ protein 1A (HSPA1A), and chemokine ligand 20 (CCL20).

As expected, DM1 affected oxidative stress-related processes in comparison with healthy controls. In particular, we found that expression of DUOX2, NOS2A, TXNRD2, LPO and NOXO1 was upregulated in DM1 patients. FA exerts protective anti-oxidant effects and has shown to improve endothelial function in patients with cardiovascular disease [28-38], In our study, we expected an effect of FA treatment on the expression of oxidative stressrelated genes in EPC. FA indeed regulated expression of DUOX2, NOS2A, NOXO1 and LPO. Unexpectedly, we identified a striking effect of FA on genes involved in developmental processes, cell adhesion and $\mathrm{G}$ protein signaling. Inhibitor of differentiation 1 (ID1) was upregulated in DM1 and normalized by FA. ID1 is a basic helixloop-helix transcription factor that lacks a DNA binding domain. Through its ability to bind to the ubiquitously expressed E protein family of basic helix-loop-helix transcription factors, it can inhibit their binding to target DNA. This important function of Id proteins confers a central role in the regulation of gene expression and hence cellular differentiation and proliferation[55,56]. Interestingly, Id knockout mice show a complete loss of EPC in the peripheral blood, which is correlated with a block in tumor neovascularization and delayed tumor growth[57].

V-maf musculoaponeurotic fibrosarcoma oncogene homolog $\mathrm{F}$ (MAFF) is a transcription factor that was downregulated in DM1 and normalized by FA. Although little is known about the functional role of MAFF in health and disease, some studies have shown that it plays a role in the cellular stress response. MAFF can bind to Nrf2, a transcription factor that activates the expression of genes with anti-oxidant response elements in their promoters $[58,59]$. This is the first time that MAFF has been described in association with DM1.

Moens et al[40] recently showed that exogenous $\mathrm{BH} 4$ could reverse pre-existing cardiac fibrosis and hypertrophy in mice. A microarray analysis was performed to identify genes that are regulated by $\mathrm{BH} 4$ in comparison to another anti-oxidant approach (Tempol). It was reported that BH4 had an effect on expression of ATP- and metabolic and $\mathrm{G}$ protein signaling-regulated genes. This indicates that FA may possess a more general modifying role in pathological processes besides its known capacity to restore NOS coupling.

We observed a decrease in EPC number in patients with DM1 compared to healthy controls consistent with other reports[21,24]. Treatment with FA only corrected for a small part the number of EPC in patients with DM1 which might be through the observed effect on ID1, modulating differentiation and proliferation, or apoptosis[60].

Further research will be needed to more closely investigate the individual role that the genes present in the set of FAregulated genes in EPC function. Signaling pathways modulated by folic acid may be potential therapeutic targets to improve endothelial progenitor cell function.

\section{Conclusion}

This study employed genome-wide profiling to elucidate the effect of DM1 and the response to FA on EPC gene expression. We observed a remarkable effect of FA on gene expression, resulting in normalization of EPC from DM1 patients to resemble those of healthy controls.

\section{Competing interests}

The authors declare that they have no competing interests.

\section{Authors' contributions}

OVO participated in the design of the study, collected the material, performed the microarray and analysis of the data, drafted and revised the manuscript. DPVDK participated in the analysis of the study and helped draft the manuscript. JOF participated in the analysis of the study and helped draft the manuscript. MP participated in interpretation and analysis of data, and revised the content critically for important intellectual content. AS participated in interpretation and analysis of data, and revised the content critically for important intellectual content. AT participated in interpretation and analysis of data, and revised the content critically for important intellectual content. SKL participated in the microarray analysis, and revised the content critically for important intellectual content. MCV participated in the design of the study, interpretation and analysis of data, and helped draft and revise the manuscript. All authors read and approved the final manuscript. 


\section{Additional material}

\section{Additional file 1}

Gene list for cluster 1 and 2. Gene lists for clusters 1 and 2 are provided, including their fold changes and FDR. These genes are differentially expressed in EPC between DM1 and healthy controls and are normalized by FA treatment.

Click here for file

[http://www.biomedcentral.com/content/supplementary/14752840-8-47-S1.pdf]

\section{Acknowledgements}

This study was supported by the Netherlands Organization for Scientific Research (NWO Vidi grant 016.096 .359 to MCV). NWO played no role in the study or submission of the manuscript for publication.

\section{References}

I. Kannel WB, McGee DL: Diabetes and cardiovascular disease. The Framingham study. Jama 1979, 24 I(19):2035-2038.

2. Sheetz MJ, King GL: Molecular understanding of hyperglycemia's adverse effects for diabetic complications. Jama 2002, 288(20):2579-2588.

3. Johnstone MT, Creager SJ, Scales KM, Cusco JA, Lee BK, Creager MA: Impaired endothelium-dependent vasodilation in patients with insulin-dependent diabetes mellitus. Circulation 1993, 88(6):25I0-25I6.

4. Nathan DM, Lachin J, Cleary P, Orchard T, Brillon DJ, Backlund JY, O'Leary DH, Genuth S: Intensive diabetes therapy and carotid intima-media thickness in type I diabetes mellitus. The New England journal of medicine 2003, 348(23):2294-2303.

5. Williams SB, Cusco JA, Roddy MA, Johnstone MT, Creager MA: Impaired nitric oxide-mediated vasodilation in patients with non-insulin-dependent diabetes mellitus. Journal of the American College of Cardiology 1996, 27(3):567-574.

6. Abaci A, Oguzhan A, Kahraman S, Eryol NK, Unal S, Arinc H, Ergin A Effect of diabetes mellitus on formation of coronary collateral vessels. Circulation 1999, 99(I7):2239-2242.

7. Creager MA, Luscher TF, Cosentino F, Beckman JA: Diabetes and vascular disease: pathophysiology, clinical consequences, and medical therapy: Part I. Circulation 2003, 108(1 2): 1527-1532.

8. Loomans CJ, De Koning EJ, Staal FJ, Rabelink TJ, Zonneveld AJ: Endothelial progenitor cell dysfunction in type I diabetes: another consequence of oxidative stress? Antioxidants \& redox signaling 2005, 7( I I- | 2): | 468-1475.

9. Dimmeler S, Haendeler J, Zeiher AM: Regulation of endothelial cell apoptosis in atherothrombosis. Current opinion in lipidology 2002, I3(5):531-536.

10. Dimmeler S, Zeiher AM: Vascular repair by circulating endothelial progenitor cells: the missing link in atherosclerosis? Journal of molecular medicine (Berlin, Germany) 2004, 82( I 0):67I-677.

11. Peichev M, Naiyer AJ, Pereira D, Zhu Z, Lane W], Williams M, Oz MC, Hicklin DJ, Witte L, Moore MA, et al.: Expression of VEGFR2 and $A C I 33$ by circulating human CD34(+) cells identifies a population of functional endothelial precursors. Blood 2000, 95(3):952-958.

12. Shi Q, Rafii S, Wu MH, Wijelath ES, Yu C, Ishida A, Fujita Y, Kothari $S$, Mohle R, Sauvage LR, et al.: Evidence for circulating bone marrow-derived endothelial cells. Blood 1998, 92(2):362-367.

13. Walter DH, Rittig K, Bahlmann FH, Kirchmair R, Silver M, Murayama T, Nishimura H, Losordo DW, Asahara T, Isner JM: Statin therapy accelerates reendothelialization: a novel effect involving mobilization and incorporation of bone marrow-derived endothelial progenitor cells. Circulation 2002, I05(25):3017-3024

14. Werner N, Junk S, Laufs U, Link A, Walenta K, Bohm M, Nickenig G: Intravenous transfusion of endothelial progenitor cells reduces neointima formation after vascular injury. Circulation research 2003, 93(2): el7-24.

15. Werner N, Priller J, Laufs U, Endres M, Bohm M, Dirnagl U, Nickenig G: Bone marrow-derived progenitor cells modulate vascular reendothelialization and neointimal formation: effect of 3hydroxy-3-methylglutaryl coenzyme a reductase inhibition. Arteriosclerosis, thrombosis, and vascular biology 2002, 22(10): I567-1572.

16. Kalka C, Masuda H, Takahashi T, Kalka-Moll WM, Silver M, Kearney $\mathrm{M}$, $\mathrm{Li} \mathrm{T}$, Isner JM, Asahara $\mathrm{T}$ : Transplantation of ex vivo expanded endothelial progenitor cells for therapeutic neovascularization. Proceedings of the National Academy of Sciences of the United States of America 2000, 97(7):3422-3427.

17. Yamaguchi J, Kusano KF, Masuo O, Kawamoto A, Silver M, Murasawa S, Bosch-Marce M, Masuda H, Losordo DW, Isner JM, et al.: Stromal cell-derived factor-I effects on ex vivo expanded endothelial progenitor cell recruitment for ischemic neovascularization. Circulation 2003, 107(9): I322-1328.

18. Asahara T, Masuda H, Takahashi T, Kalka C, Pastore C, Silver M, Kearne M, Magner M, Isner JM: Bone marrow origin of endothelial progenitor cells responsible for postnatal vasculogenesis in physiological and pathological neovascularization. Circulation research 1999, 85(3):22I-228.

19. Schachinger V, Assmus B, Britten MB, Honold J, Lehmann R, Teupe C, Abolmaali ND, Vogl TJ, Hofmann WK, Martin H, et al.: Transplantation of progenitor cells and regeneration enhancement in acute myocardial infarction: final one-year results of the TOPCARE-AMI Trial. Journal of the American College of Cardiology 2004, 44(8): 1690-1699.

20. Hill JM, Zalos G, Halcox JP, Schenke WH, Waclawiw MA, Quyyumi AA, Finkel T: Circulating endothelial progenitor cells, vascular function, and cardiovascular risk. The New England journal of medicine 2003, 348(7):593-600.

21. Loomans CJ, de Koning EJ, Staal FJ, Rookmaaker MB, Verseyden C, de Boer HC, Verhaar MC, Braam B, Rabelink TJ, van Zonneveld AJ: Endothelial progenitor cell dysfunction: a novel concept in the pathogenesis of vascular complications of type I diabetes. Diabetes 2004, 53(1):195-199.

22. Schatteman GC, Hanlon HD, Jiao C, Dodds SG, Christy BA: Bloodderived angioblasts accelerate blood-flow restoration in diabetic mice. The Journal of clinical investigation 2000, I06(4):57I-578.

23. Tamarat $R$, Silvestre $J S$, Le Ricousse-Roussanne $S$, Barateau $V$, Lecomte-Raclet L, Clergue M, Duriez M, Tobelem G, Levy BI: Impairment in ischemia-induced neovascularization in diabetes: bone marrow mononuclear cell dysfunction and therapeutic potential of placenta growth factor treatment. The American journal of pathology 2004, 1 64(2):457-466.

24. Tepper OM, Galiano RD, Capla JM, Kalka C, Gagne PJ, Jacobowitz GR, Levine JP, Gurtner GC: Human endothelial progenitor cells from type II diabetics exhibit impaired proliferation, adhesion, and incorporation into vascular structures. Circulation 2002, 106(22):278I-2786.

25. Sorrentino SA, Bahlmann FH, Besler C, Muller M, Schulz S, Kirchhoff N, Doerries C, Horvath T, Limbourg A, Limbourg F, et al.: Oxidant stress impairs in vivo reendothelialization capacity of endothelial progenitor cells from patients with type 2 diabetes mellitus: restoration by the peroxisome proliferatoractivated receptor-gamma agonist rosiglitazone. Circulation 2007, I I 6(2):163-173.

26. Thum T, Fraccarollo $D$, Schultheiss $M$, Froese $S$, Galuppo $P$, Widder JD, Tsikas D, Ertl G, Bauersachs J: Endothelial nitric oxide synthase uncoupling impairs endothelial progenitor cell mobilization and function in diabetes. Diabetes 2007, 56(3):666-674.

27. Stroes ES, van Faassen EE, Yo M, Martasek P, Boer P, Govers R, Rabelink TJ: Folic acid reverts dysfunction of endothelial nitric oxide synthase. Circulation research 2000, 86(I I): I I29-I I34.

28. Antoniades C, Shirodaria C, Warrick N, Cai S, de Bono J, Lee J, Leeson $P$, Neubauer S, Ratnatunga C, Pillai R, et al.: 5-methyltetrahydrofolate rapidly improves endothelial function and decreases superoxide production in human vessels: effects on vascular tetrahydrobiopterin availability and endothelial nitric oxide synthase coupling. Circulation 2006, II4(II): II 193-I20I.

29. Doshi SN, McDowell IF, Moat SJ, Lang D, Newcombe RG, Kredan MB, Lewis MJ, Goodfellow J: Folate improves endothelial function in coronary artery disease: an effect mediated by reduc- 
tion of intracellular superoxide? Arteriosclerosis, thrombosis, and vascular biology 200I, 2 I(7): I I96-I 202.

30. Bellamy MF, McDowell IF, Ramsey MW, Brownlee M, Newcombe RG, Lewis MJ: Oral folate enhances endothelial function in hyperhomocysteinaemic subjects. European journal of clinical investigation 1999, 29(8):659-662.

31. Usui M, Matsuoka H, Miyazaki H, Ueda S, Okuda S, Imaizumi T: Endothelial dysfunction by acute hyperhomocyst(e)inaemia: restoration by folic acid. Clin Sci (Lond) 1999, 96(3):235-239.

32. Woo KS, Chook P, Lolin YI, Sanderson JE, Metreweli C, Celermajer DS: Folic acid improves arterial endothelial function in adults with hyperhomocystinemia. Journal of the American College of Cardiology 1999, 34(7):2002-2006.

33. Verhaar MC, Wever RM, Kastelein JJ, van Dam T, Koomans HA, Rabelink T): 5-methyltetrahydrofolate, the active form of folic acid, restores endothelial function in familial hypercholesterolemia. Circulation 1998, 97(3):237-241.

34. Verhaar MC, Wever RM, Kastelein J], van Loon D, Milstien S, Koomans HA, Rabelink TJ: Effects of oral folic acid supplementation on endothelial function in familial hypercholesterolemia. A randomized placebo-controlled trial. Circulation 1999, 100(4):335-338.

35. Wilmink HW, Stroes ES, Erkelens WD, Gerritsen WB, Wever R, Banga JD, Rabelink TJ: Influence of folic acid on postprandial endothelial dysfunction. Arteriosclerosis, thrombosis, and vascular biology 2000, 20(I): 185-188.

36. Pena AS, Wiltshire E, Gent R, Hirte C, Couper J: Folic acid improves endothelial function in children and adolescents with type I diabetes. The Journal of pediatrics 2004, 144(4):500-504.

37. Title LM, Ur E, Giddens K, McQueen MJ, Nassar BA: Folic acid improves endothelial dysfunction in type 2 diabetes - an effect independent of homocysteine-lowering. Vascular medicine (London, England) 2006, II (2): I0I-109.

38. van Etten RW, de Koning EJ, Verhaar MC, Gaillard CA, Rabelink TJ: Impaired NO-dependent vasodilation in patients with Type II (non-insulin-dependent) diabetes mellitus is restored by acute administration of folate. Diabetologia 2002, 45(7): $1004-1010$.

39. Moens AL, Champion HC, Claeys MJ, Tavazzi B, Kaminski PM, Wolin MS, Borgonjon DJ, Van Nassauw L, Haile A, Zviman M, et al.: Highdose folic acid pretreatment blunts cardiac dysfunction during ischemia coupled to maintenance of high-energy phosphates and reduces postreperfusion injury. Circulation 2008, II7(14): $1810-1819$

40. Moens AL, Takimoto E, Tocchetti CG, Chakir K, Bedja D, Cormaci G, Ketner EA, Majmudar M, Gabrielson K, Halushka MK, et al. Reversal of cardiac hypertrophy and fibrosis from pressure overload by tetrahydrobiopterin: efficacy of recoupling nitric oxide synthase as a therapeutic strategy. Circulation 2008, I I 7(20):2626-2636

4I. Westerweel PE, Hoefer IE, Blankestijn PJ, de Bree P, Groeneveld D, van Oostrom O, Braam B, Koomans HA, Verhaar MC: End-stage renal disease causes an imbalance between endothelial and smooth muscle progenitor cells. American journal of physiology 2007, 292(4):FI I32-II40.

42. Wright GW, Simon RM: A random variance model for detection of differential gene expression in small microarray experiments. Bioinformatics 2003, 19( I 8):2448-2455.

43. Korn EL, Troendle JF, McShane LM, Simon R: Controlling the number of false discoveries: application to high-dimensional genomic data. Journal of Statistical Planning and Inference 2004, 1 24:379-398.

44. Simon R, Korn E, McShane L, Radmacher M, Wright G, Zhao Y: Design and Analysis of DNA Microarray Investigations. New York: Springer; 2003.

45. Seals DF, Courtneidge SA: The ADAMs family of metalloproteases: multidomain proteins with multiple functions. Genes \& development 2003, I7(1):7-30.

46. van Hinsbergh VW, Engelse MA, Quax PH: Pericellular proteases in angiogenesis and vasculogenesis. Arteriosclerosis, thrombosis, and vascular biology 2006, 26(4):716-728.

47. Wang Y, Subudhi SK, Anders RA, Lo J, Sun Y, Blink S, Wang Y, Wang J, Liu X, Mink K, et al.: The role of herpesvirus entry mediator as a negative regulator of $\mathrm{T}$ cell-mediated responses. The Journal of clinical investigation 2005, I I5(3):7I I-7I7.
48. Cheung TC, Steinberg MW, Oborne LM, Macauley MG, Fukuyama S, Sanjo H, D'Souza C, Norris PS, Pfeffer K, Murphy KM, et al:: Unconventional ligand activation of herpesvirus entry mediator signals cell survival. Proceedings of the National Academy of Sciences of the United States of America 2009, I 06( I 5):6244-6249.

49. Kang YM, Kim SY, Kang JH, Han SW, Nam EJ, Kyung HS, Park JY, Kim IS: LIGHT up-regulated on B lymphocytes and monocytes in rheumatoid arthritis mediates cellular adhesion and metalloproteinase production by synoviocytes. Arthritis and rheumatism 2007, 56(4): I I06-III 7

50. Pierer M, Schulz A, Rossol M, Kendzia E, Kyburz D, Haentzschel H, Baerwald $C$, Wagner U: Herpesvirus entry mediator-Ig treatment during immunization aggravates rheumatoid arthritis in the collagen-induced arthritis model. J Immunol 2009 , I 82(5):3|39-3|45.

5I. Sandberg WJ, Halvorsen B, Yndestad A, Smith C, Otterdal K, Brosstad FR, Froland SS, Olofsson PS, Damas JK, Gullestad L, et al.: Inflammatory interaction between LIGHT and proteinaseactivated receptor- 2 in endothelial cells: potential role in atherogenesis. Circulation research 2009, 104(I):60-68.

52. Padmos RC, Schloot NC, Beyan H, Ruwhof C, Staal FJ, de Ridder D, Aanstoot HJ, Lam-Tse WK, de Wit H, de Herder C, et al.: Distinct monocyte gene-expression profiles in autoimmune diabetes. Diabetes 2008, 57(10):2768-2773.

53. Kaizer EC, Glaser CL, Chaussabel D, Banchereau J, Pascual V, White PC: Gene expression in peripheral blood mononuclear cells from children with diabetes. The Journal of clinical endocrinology and metabolism 2007, 92(9):3705-37II.

54. Rehman J, Li J, Orschell CM, March KL: Peripheral blood "endothelial progenitor cells" are derived from monocyte/ macrophages and secrete angiogenic growth factors. Circulation 2003, I07(8): I I64-II69.

55. Lasorella $A$, Uo $T$, lavarone $A$ : Id proteins at the cross-road of development and cancer. Oncogene 200I, 20(58):8326-8333.

56. Ruzinova MB, Benezra R: Id proteins in development, cell cycle and cancer. Trends in cell biology 2003, I3(8):410-4I8.

57. Lyden D, Hattori K, Dias S, Costa C, Blaikie P, Butros L, Chadburn A Heissig B, Marks W, Witte L, et al.: Impaired recruitment of bone-marrow-derived endothelial and hematopoietic precursor cells blocks tumor angiogenesis and growth. Nature medicine 200I, 7(I I): II94-I20I.

58. Katsuoka F, Motohashi H, Ishii T, Aburatani H, Engel JD, Yamamoto M: Genetic evidence that small maf proteins are essential for the activation of antioxidant response element-dependent genes. Molecular and cellular biology 2005, 25( 1 8):8044-805 I.

59. Blank V: Small Maf proteins in mammalian gene control: mere dimerization partners or dynamic transcriptional regulators? Journal of molecular biology 2008, 376(4):9|3-925.

60. Wu TG, Li WH, Lin ZQ, Wang LX: Effects of folic acid on cardiac myocyte apoptosis in rats with streptozotocin-induced diabetes mellitus. Cardiovascular drugs and therapy/sponsored by the International Society of Cardiovascular Pharmacotherapy 2008, 22(4):299-304.

Publish with Bio Med Central and every scientist can read your work free of charge

"BioMed Central will be the most significant development for disseminating the results of biomedical research in our lifetime. "

Sir Paul Nurse, Cancer Research UK

Your research papers will be:

- available free of charge to the entire biomedical community

- peer reviewed and published immediately upon acceptance

- cited in PubMed and archived on PubMed Central

- yours - you keep the copyright
BioMedcentral 